\title{
Assessment of advice to reduce dietary fat and non-milk extrinsic sugar in a free-living male population
}

\author{
Sandra Drummond* and Terry Kirk \\ Centre for Nutrition and Food Research, Queen Margaret College, Clerwood Terrace, Edinburgh EH12 8TS, UK
}

Submitted 10 September 1998: Accepted 10 March 1999

\begin{abstract}
Objective: To compare the effect of advice to reduce both dietary fat and sugar with advice to reduce fat alone on subsequent dietary intake in Scottish men.

Design: A parallel design intervention study was employed to measure compliance to the two types of dietary advice. Subjects were randomly assigned to Group 1 (advice to reduce fat and non-milk extrinsic (NME) sugar), Group 2 (advice to reduce fat only, ad libitum sugar) or a control Group 0 (no advice). Compliance was assessed by two 4-day food diaries over 6 months.

Setting: The study was conducted in the Strathclyde area of Scotland.

Subjects: Subjects were normal to moderately overweight Scottish men. The men recruited were non-dieting and volunteered for a 'healthy eating' study with the aim to improve the 'healthiness' of their diet.

Results: Groups 1 and 2 achieved the dietary target for fat, reducing their mean intake to below 35\% energy. Group 1 achieved a statistically significant reduction in percentage energy from NME sugar in the short term (6 weeks), decreasing their mean intake from $9.9 \%$ to $7.2 \%$ energy. This initial decrease appeared to slip back towards baseline levels at 6 months (8.1\% energy from NME sugar) and was no longer significantly different from baseline. At 6 months Group 1 reported a significantly lower mean energy intake than at baseline, whereas Group 2 adjusted for an initial decrease in energy intake and by 6 months energy intakes were not significantly different from baseline intakes. Group 2 appeared to compensate for the absolute reduction in dietary fat with a slight increase in total sugars and the maintenance of NME sugar intakes.

Conclusions: Subjects in Group 1 complied with advice to reduce both fat and sugar over 6 weeks but to a lesser extent over 6 months. The $1.8 \%$ reduction in percentage energy from NME sugars in Group 1 at 6 months may not have reached significance due to the small sample size. Alternatively it may be that free-living populations find it hard to maintain concurrent reductions in fat and sugar owing to the welldocumented inverse relationship between intakes of these macronutrients when expressed as a proportion of energy.
\end{abstract}

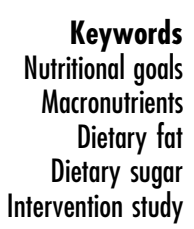

The publication of several sets of dietary guidelines aimed at improving the UK $\operatorname{diet}^{1-3}$ has resulted in little change in eating habits over the last decade. In 1996, the Scottish Office Department of Health ${ }^{4}$ published a report recommending reductions in the percentage energy from dietary fat and sugar. As yet, there has been little assessment of the value of this type of advice to the free-living population, for example, the practicality of the recommendations and whether the dietary modifications can be sustained long term.

There is some evidence that multiple dietary goals are difficult to achieve for the general public ${ }^{5}$, after nutritional counselling ${ }^{6}$ and even for health professionals ${ }^{7,8}$. Giving advice on dietary modifications requires an understanding of the implications of such a change for the overall balance of the diet and how changes to one nutrient might affect another. One example is how advice to reduce sugar consumption might affect subsequent fat intake. A number of researchers have described, in free-living populations, the existence of an inverse relationship between percentage energy from fat and the percentage energy from sugar in the $\operatorname{diet}^{9-11}$. Thus, consumers achieving low fat diets tend to have high sugar intakes, raising the question whether restrictions in sugar intake may result in a counterproductive rise in fat intake.

Naismith and Rhodes ${ }^{12}$ demonstrated this effect in an intervention study. When sugar was covertly removed 
from subjects' diets over a 2-week period using substitution with artificial sweeteners there was a significant increase in intake of calories from fat. Similarly in a study by Lavin et al. ${ }^{13}$, female restrained eaters consumed a higher fat diet for 24 hours after being given diet drinks compared with occasions when they were given sugar-containing drinks.

These studies suggest that simultaneous reductions in dietary fat and sugar may be difficult to achieve. The present study aims not only to test this premise but to investigate whether current advice to alter fat and sugar intakes is sustainable in a free-living population. This information is urgently needed to improve the efficacy of nutritional advice.

\section{Methods}

\section{Subjects}

Recruitment of subjects was restricted to men over the age of 40 years, since our target subjects were individuals who would be likely to be asked to follow healthy eating advice, to reduce the risk of chronic disease and/or for weight management. Subjects were recruited from the Strathclyde Police Department, which is a predominately male organization. Over a 12-month period from March 1996 to February 1997, 108 men responded to an initial letter sent asking for volunteers to take part in a 'healthy eating' study. Subjects were excluded if they suffered from any chronic illness which might affect food intake, if they were on prescribed medication or if they were following a weight-reducing or other special diet. Using these criteria 93 men were selected to participate in the study. All 93 subjects completed the 6-month study and received $£ 30$ compensation for their time. Ethical approval was given for the study by the Queen Margaret College Ethics Committee.

\section{Antbropometry}

Body weight was measured to the nearest $0.5 \mathrm{~kg}$ using portable scales, and body mass index (BMI) was calculated using self-reported height (BMI = weight/ height ${ }^{2}$ ). Per cent body fat was calculated from skinfold thicknesses from biceps, triceps, subscapular and suprailiac sites ${ }^{14}$. Waist and hip measurements were measured to the nearest $1.0 \mathrm{~cm}$ and the waist to hip ratio calculated.

\section{Dietary assessment and dietary advice}

Baseline energy and nutrient intakes were assessed using an unweighed inventory method over 7 days. Subjects were instructed how to record their food intake and were given supporting literature detailing how to keep a diet diary. The subjects were randomly assigned to one of three groups - two intervention groups and a control group.
- Group 0: Received no dietary advice.

- Group 1: Received advice on how to reduce both dietary fats and NME sugars and how to replace them with complex carbohydrates (see Appendix 1).

- Group 2: Received advice on how to reduce dietary fat only and how to replace it with a mixture of complex carbohydrates and NME sugars (see Appendix 2).

Individuals were given advice in a single session, on a one-to-one basis by the researcher. The true purpose of the study (i.e. to compare the effectiveness of two types of messages) was not revealed to the subjects. The subjects were counselled that the advice given to them was specific to them and that their colleagues may be receiving different advice. Support information in the form of a dietary advice booklet appropriate to the subject's group was also supplied. Informed consent was obtained from all subjects and the partner/wife of each subject signed a consent form stating that they would support their partner in the study. There were five single men in the study: two in Group 0, two in Group 1 and one in Group 2. Subjects from Group 1 and 2 were given a checklist highlighting the dietary changes asked of them, as a memory aid, to display in a prominent place in their home/kitchen, to which they could refer on a weekly basis.

The effect of the dietary advice on subsequent intake was assessed on two occasions post-intervention, after 6 weeks and 6 months, by requesting the subjects to record a 4-day diet diary (three weekdays and one weekend day). Subjects involved in shift work were instructed to record their diet over the same work shift for each of the recording periods. Night shifts were avoided. Between 6 weeks and 6 months there was no contact between the researcher and the subject. Subjects in the control group were also followed up at these same intervals and were asked to record their diets in an identical fashion.

\section{Dietary analysis}

Energy and nutrient intakes were assessed using an unweighed inventory method. Subjects described portion sizes in household measures (cupful, spoonful, etc.) or as small, medium or large portions. Portion sizes were converted into weight (grams) by the researcher (SD) using the Food Portion Sizes booklet ${ }^{15}$. Energy and macronutrient analysis of all diet records (as per cent food energy and in grams) was performed using the McCance and Widdowson food tables ${ }^{16}$ in the form of the CompEat 4 nutritional software package. Foods consumed were also categorized into 12 main food groups ${ }^{17}$.

\section{Estimation of intake of sugars}

Additional compositional data on added sugars was 
obtained from food companies. 'Total sugar' includes all sugars, intrinsic and extrinsic (including NME sugars). NME sugar was calculated as that sugar not naturally present within the intracellular structure of foods (fruit, vegetables and grains) plus 50\% of the sugar in refined or processed fruits, vegetables and cereal products $^{18}$. Sugars in fruit juices were deemed as 'extrinsic'19. Thus NME sugar=all added sugars + sugars in fruit juice $+50 \%$ sugars in processed foods.

\section{Statistical analysis}

Statistical analyses were performed using the SPSS software package (Version 4.0, SPSS Inc., Chicago). Within and between group mean intakes of macronutrients and energy at baseline, 6 weeks and 6 months were analysed using repeated measures analysis of variance (ANOVA). When statistically significant effects were encountered $(P<0.05)$, comparisons of means were made using the Bonferroni post hoc multiple range test to ascertain which specific means differed. A value of $P<0.05$ was used as the criterion for statistical significance. Within group mean intakes of different types of foods and food groups at baseline were compared with 6 weeks and 6 months post-intervention using a paired sample $t$-test.

\section{Results}

\section{Subject profiles}

Table 1 shows the baseline anthropometric measurements for each of the three groups. There were no significant differences between groups for age, body weight, BMI, per cent body fat and the waist to hip ratio.

\section{Dietary underreporting}

Diet records giving an estimated energy intake at baseline which fell below the cut-off of $1.10 \times$ basal metabolic rate (BMR) were excluded from the analysis on the grounds that they were likely to indicate underreporting $^{20}$. BMR was estimated from weight, age and sex using the Schofield equations ${ }^{21}$. Hence 16 out of the 93 subjects were deemed to be underreporters. The group of suspected underreporters were assessed separately for age, body weight, BMI, per cent body fat and waist to hip ratio (Table 1). In comparison to the valid reporters, they had a similar mean age, a significantly higher body weight $(P<0.05)$, and similar body fatness, BMI and waist to hip ratios.

Although no subjects actually dropped out of the study, there were three missing values over the 6month study period. These were due to three subjects (two in the control group and one in Group 1) who completed diet diaries at baseline and 6 months but not at the 6-week stage. It was decided to use complete datasets only, since inclusion of these subjects did not affect the outcome, leaving a total of 74 subjects for final statistical analysis (i.e. Group 0: $n=25$; Group 1: $n=24$; Group 2: $n=25$ ).

\section{Witbin group changes}

Group O: In the control group there were no significant changes in energy intake over the 6-month period. Similarly there were no significant changes in the percentage energy derived from macronutrients throughout the 6-month study (Table 2).

Group 1: In the group receiving advice to reduce both fat and NME sugars there was a substantial decrease in energy intake of $1.78 \mathrm{MJ} \mathrm{day}^{-1}$ at 6 weeks post-intervention. Energy intake increased at 6 months, although remained lower than baseline (by $1.31 \mathrm{MJ} \mathrm{day}^{-1}$ ). The percentage of energy from fat also decreased significantly from baseline at both points post-intervention, bringing the value down from around 39\% to a mean of $33.7 \%$. Other dietary changes included a significant increase in percentage energy from carbohydrate (by $3.6 \%$ ) between baseline and 6 months (as a result of an increase in percentage energy from starch). There was a significant decrease in percentage energy from NME sugar between baseline and 6 weeks post-intervention. However the decrease between baseline and 6 months was not significant. There were no changes in percentage energy from total sugars throughout the 6month study. An increase in percentage energy from protein was observed at 6 weeks (by $2.1 \%$ ) but not at 6 months.

Table 3 shows that in line with the decrease in energy intake, absolute intakes of all macronutrients decreased

Table 1 Profile of subjects in Groups 0,1 and 2 and the underreporters at baseline

\begin{tabular}{lccccc}
\hline & $\begin{array}{c}\text { Total, } n=74 \\
\text { (SD) }\end{array}$ & $\begin{array}{c}\text { Group 0, } n=25 \\
\text { (SD) }\end{array}$ & $\begin{array}{c}\text { Group 1, } n=24 \\
\text { (SD) }\end{array}$ & $\begin{array}{c}\text { Group 2, } n=25 \\
\text { (SD) }\end{array}$ & $\begin{array}{c}\text { Underreporters, } n=16 \\
\text { (SD) }\end{array}$ \\
\hline Age (years) & $46.3(3.72)$ & $45.9(3.59)$ & $46.0(3.82)$ & $46.8(3.85)$ & $46.6(4.53)$ \\
Weight (kg) & $89.8^{*}(11.16)$ & $88.9(10.8)$ & $89.7(8.71)$ & $90.7(13.94)$ & $96.6^{*}(10.75)$ \\
BMl (kg m ${ }^{-2}$ ) & $27.7(3.20)$ & $27.4(2.69)$ & $27.5(3.10)$ & $28.2(3.79)$ & $28.8(3.24)$ \\
Waist to hip ratio & $0.9(0.06)$ & $0.9(0.05)$ & $0.9(0.06)$ & $0.9(0.06)$ & $0.9(0.04)$ \\
\% Body fat & $24.1(4.50)$ & $24.7(3.52)$ & $23.8(4.97)$ & $23.9(5.03)$ & $26.1(3.26)$ \\
\hline
\end{tabular}

*Using a two-tailed $t$-test, values differ significantly at a significance level of $P<0.05$. 
Table 2 Changes in macronutrient intake (percentage food energy) within Groups 0, 1 and 2 over the 6-month intervention period, showing the means and SD in parentheses

\begin{tabular}{|c|c|c|c|}
\hline & Baseline & 6 weeks & 6 months \\
\hline $\begin{array}{l}\text { \% Fat } \\
\text { Group } 0 \\
\text { Group } 1 \\
\text { Group } 2\end{array}$ & $\begin{array}{l}36.8(4.80) \\
38.8(4.93) \\
40.2(4.0)\end{array}$ & $\begin{array}{l}37.2(6.46) \\
34.0^{*}(5.15) \\
32.2^{*}(5.81)\end{array}$ & $\begin{array}{l}38.2(5.59) \\
33.4^{*}(5.76) \\
32.2^{*}(7.46)\end{array}$ \\
\hline $\begin{array}{l}\% \text { CHO } \\
\text { Group } 0 \\
\text { Group } 1 \\
\text { Group } 2\end{array}$ & $\begin{array}{l}46.2(5.05) \\
44.5(4.83) \\
43.7(4.97)\end{array}$ & $\begin{array}{l}46.2(5.84) \\
46.9(5.29) \\
48.9(6.38)\end{array}$ & $\begin{array}{l}44.9(5.93) \\
48.1^{*}(5.69) \\
49.4^{*}(8.35)\end{array}$ \\
\hline $\begin{array}{l}\text { \% Starch } \\
\text { Group } 0 \\
\text { Group } 1 \\
\text { Group } 2\end{array}$ & $\begin{array}{l}28.7(4.60) \\
27.0(3.72) \\
26.8(3.48)\end{array}$ & $\begin{array}{l}28.0(6.27) \\
30.4^{*}(4.30) \\
28.8(4.20)\end{array}$ & $\begin{array}{l}28.9(4.60) \\
31.3^{*}(5.98) \\
29.4(5.58)\end{array}$ \\
\hline $\begin{array}{c}\% \text { Total sug } \\
\text { Group } 0 \\
\text { Group } 1 \\
\text { Group } 2\end{array}$ & $\begin{array}{l}16.9(4.85) \\
17.0(5.42) \\
16.5(5.52)\end{array}$ & $\begin{array}{l}17.5(7.68) \\
15.9(4.91) \\
19.9^{*}(6.06)\end{array}$ & $\begin{array}{l}15.7(5.65) \\
16.5(4.72) \\
19.6(7.05)\end{array}$ \\
\hline $\begin{array}{c}\% \text { NME sug } \\
\text { Group 0 } \\
\text { Group } 1 \\
\text { Group } 2\end{array}$ & $\begin{array}{l}9.8(3.59) \\
9.9(4.71) \\
9.3(4.50)\end{array}$ & $\begin{array}{c}10.6(6.79) \\
7.2^{*}(3.05) \\
11.0(4.71)\end{array}$ & $\begin{array}{r}8.8(4.22) \\
8.1(3.32) \\
10.1(4.64)\end{array}$ \\
\hline $\begin{array}{l}\text { \% Protein } \\
\text { Group } 0 \\
\text { Group } 1 \\
\text { Group } 2\end{array}$ & $\begin{array}{l}16.8(2.66) \\
16.6(2.82) \\
16.0(2.81)\end{array}$ & $\begin{array}{l}16.5(2.84) \\
19.1^{*}(3.30) \\
18.7^{*}(3.79)\end{array}$ & $\begin{array}{l}16.7(1.95) \\
18.4(3.47) \\
18.2(4.47)\end{array}$ \\
\hline $\begin{array}{r}\% \text { Alcohol } \\
\text { Group } 0 \\
\text { Group } 1 \\
\text { Group } 2\end{array}$ & $\begin{array}{l}6.8(4.30) \\
5.1(6.39) \\
6.4(5.76)\end{array}$ & $\begin{array}{l}7.4(6.40) \\
6.3(8.20) \\
7.3(9.29)\end{array}$ & $\begin{array}{l}7.7(5.38) \\
6.0(6.90) \\
6.2(6.48)\end{array}$ \\
\hline
\end{tabular}

*Values differ significantly from the baseline value in their group $(P<0.05)$.

significantly throughout the 6-month study. Fat decreased between baseline and 6 weeks and 6 months (mean decrease $=28.3 \mathrm{~g} \mathrm{day}^{-1}$ ). Total carbohydrate decreased between baseline and 6 weeks (by $43.4 \mathrm{gday}^{-1}$ ) largely as a result of the decrease in absolute intake of total sugar. Intakes of absolute levels of NME sugars were significantly lower than baseline throughout the 6-month study (mean decrease $=$ $22.8 \mathrm{~g} \mathrm{day}^{-1}$ ).

Group 2: The group receiving advice to reduce fat only significantly reduced energy intake during the first 6 weeks post-intervention (Table 2). The decrease in energy intake at 6 weeks tended to be of a smaller magnitude $\left(1.5 \mathrm{MJ} \mathrm{day}^{-1}\right)$, than Group 1 at 6 weeks. By 6 months there was no significant difference in energy intake compared with their baseline intake. Like Group 1, Group 2 decreased the percentage energy from fat from baseline to 6 weeks and 6 months (by 8.0\%) bringing the baseline level of $40.2 \%$ down to $32.2 \%$. There was a significant increase in percentage energy from carbohydrate (by 5.7\%) from baseline to 6 months. This was the result of the cumulative effect of small increases (not significant) in both percentage starch and percentage total sugar. Intakes of percentage energy from NME sugars at 6 weeks and 6 months were similar to baseline levels. An increase in percentage energy from protein (2.7\%) was observed at 6 weeks only.

Table 3 shows that the only significant change in absolute macronutrient intakes was a decrease in fat intake from baseline to 6 weeks and to 6 months (mean decrease $=30.0 \mathrm{~g} \mathrm{day}^{-1}$ ).

\section{Between group differences}

\section{Daily energy intakes}

Energy intakes did not significantly differ between groups at baseline, nor at 6 weeks or 6 months postintervention.

Macronutrient intakes (percentage food energy) There was a significant difference at baseline in percentage energy from fat between Group 0 (36.8\%) and Group $2(40.2 \%)(P<0.05)$. However at 6 weeks this had reversed with Group 2 having a significantly lower percentage energy intake from fat $(32.2 \%)$ than Group $0(37.2 \%, P<0.05)$. At 6 months both Groups 1 and 2 had a significantly lower percentage fat intake (33.4\% and 32.2\%, respectively) than Group 0 (38.2\%, $P<0.05)$. There were no significant differences in percentage energy from fat between Groups 1 and 2 .

There were no differences in percentage energy from carbohydrate, starch or total sugar throughout the study between groups.

Group 1 had a lower percentage energy from NME sugar at 6 weeks $(7.2 \%)$ than Group $2(11.0 \%, P<$ $0.05)$. There were no differences in percentage energy from NME sugar between groups at 6 months. Per cent energy from protein was significantly higher in Group 1 (19.1\%) than Group $0(16.5 \%)$ at 6 weeks $(P<0.05)$.

\section{Macronutrient intakes $\left(\mathrm{gday}^{-1}\right)$}

There were no differences in daily intakes of macronutrients in absolute terms between groups at baseline. At 6 weeks Group 1 had a lower intake of NME sugar $\left(37.9 \mathrm{~g} \mathrm{day}^{-1}\right)$ than Group $0\left(64.3 \mathrm{~g} \mathrm{day}^{-1}, P<\right.$ 0.05). At 6 months post-intervention there were no significant differences in sugar intakes between the three groups.

\section{Changes in consumption of different types offood}

Foods eaten were categorized into 12 food groups fats and oils, milk and milk products, meat and meat products, eggs and egg dishes, cereal and cereal products, vegetables and vegetable dishes, sugar, preserves and snacks, fruit and fruit juice, fish and fish products, nuts and seeds, alcohol and beverages. Percentage energy from the food groups was calculated and compared between Groups 0, 1 and 2 (Table 4). 
Table 3 Changes in macronutrient intake (grams) within Groups 0, 1 and 2 over the 6month intervention period, showing the means and SD in parentheses

\begin{tabular}{|c|c|c|c|}
\hline & Baseline & 6 weeks & 6 months \\
\hline $\begin{array}{c}\text { Energy inta } \\
\text { Group } 0 \\
\text { Group } 1 \\
\text { Group } 2\end{array}$ & $\begin{array}{l}10.44(1.67) \\
10.74(2.24) \\
11.04(1.67)\end{array}$ & $\begin{array}{c}10.13(1.79) \\
8.96 \dagger(1.69) \\
9.54 \dagger(1.92)\end{array}$ & $\begin{array}{c}10.14(2.02) \\
9.43 \dagger(2.51) \\
10.27(2.78)\end{array}$ \\
\hline $\begin{array}{l}\text { Fat (g) } \\
\text { Group } 0 \\
\text { Group } 1 \\
\text { Group } 2\end{array}$ & $\begin{array}{r}94.0(22.0) \\
104.6(28.1) \\
108.4(2.1)\end{array}$ & $\begin{array}{l}91.7(28.5) \\
74.4 \dagger(18.7) \\
75.7 \dagger(28.1)\end{array}$ & $\begin{array}{l}92.6(21.4) \\
78.3 \dagger(24.4) \\
81.2 \dagger(30.9)\end{array}$ \\
\hline $\begin{array}{l}\mathrm{CHO}(\mathrm{g}) \\
\text { Group } 0 \\
\text { Group } 1 \\
\text { Group } 2\end{array}$ & $\begin{array}{l}280.6(55.6) \\
289.1(81.7) \\
286.0(70.6)\end{array}$ & $\begin{array}{l}269.3(60.7) \\
245.7 \dagger(55.5) \\
272.1(71.5)\end{array}$ & $\begin{array}{l}262.2(63.5) \\
271.8(96.6) \\
297.8(97.4)\end{array}$ \\
\hline $\begin{array}{r}\text { Starch }(\mathrm{g}) \\
\text { Group } 0 \\
\text { Group } 1 \\
\text { Group } 2\end{array}$ & $\begin{array}{l}174.2(37.1) \\
174.4(49.9) \\
170.3(54.6)\end{array}$ & $\begin{array}{l}161.4(35.5) \\
158.7 \dagger(34.5) \\
158.5(36.7)\end{array}$ & $\begin{array}{l}168.0(41.4) \\
175.1(60.7) \\
174.1(47.8)\end{array}$ \\
\hline $\begin{array}{c}\text { Total sugar } \\
\text { Group } 0 \\
\text { Group } 1 \\
\text { Group } 2\end{array}$ & $\begin{array}{l}103.4(36.8) \\
111.7(46.1) \\
108.4(42.5)\end{array}$ & $\begin{array}{c}104.3(58.0) \\
84.3 \dagger(31.5) \\
112.2(47.8)\end{array}$ & $\begin{array}{r}92.5(41.7) \\
95.4(48.1) \\
121.4(64.5)\end{array}$ \\
\hline $\begin{array}{c}\text { NME sugar } \\
\text { Group } 0 \\
\text { Group } 1 \\
\text { Group } 2\end{array}$ & $\begin{array}{l}60.0(26.3) \\
65.0(34.1) \\
61.9(33.6)\end{array}$ & $\begin{array}{l}64.3(48.6) \\
37.9 \dagger(15.9) \\
61.9(33.1)\end{array}$ & $\begin{array}{l}51.7(29.6) \\
46.5 \dagger(25.9) \\
64.3(44.1)\end{array}$ \\
\hline $\begin{array}{r}\text { Protein (g) } \\
\text { Group 0 } \\
\text { Group } 1 \\
\text { Group } 2\end{array}$ & $\begin{array}{l}94.8(14.9) \\
98.6(20.6) \\
96.2(18.9)\end{array}$ & $\begin{array}{l}89.1(14.5) \\
93.9(23.0) \\
95.2(21.4)\end{array}$ & $\begin{array}{l}91.2(17.8) \\
95.5(28.2) \\
98.4(21.8)\end{array}$ \\
\hline $\begin{array}{c}\text { Alcohol (g) } \\
\text { Group } 0 \\
\text { Group } 1 \\
\text { Group } 2\end{array}$ & $\begin{array}{l}24.5(16.6) \\
17.6(20.3) \\
23.5(20.7)\end{array}$ & $\begin{array}{l}26.5(24.2) \\
20.7(27.4) \\
21.7(24.1)\end{array}$ & $\begin{array}{l}26.1(19.0) \\
17.1(20.2) \\
22.3(25.7)\end{array}$ \\
\hline
\end{tabular}

*Energy intake includes energy derived from alcohol.

†Values differ significantly from the baseline value in their group $(P<0.05)$.

Group O: There were no significant changes in the various food groups in Group 0 throughout the 6-month study.

Group 1: Group 1 significantly decreased intake of fats and oils at 6 months. Although there was no change in total milk and milk products intake, closer examination revealed that there were significant changes in the type of milk consumed. Group 1 decreased whole milk consumption while increasing the amount of semiskimmed milk, with no change in skimmed milk consumption.

At 6 weeks and 6 months there was a significant increase in cereals, mainly owing to an increase in the amount of bread eaten, with smaller increases in pasta, rice and breakfast cereals. There were significant reductions in sugar, preserves and snacks at 6 weeks. Subjects appeared to achieve this by reducing consumption of chocolate, crisps and biscuits. However this was not sustained at 6 months, when consumption was not significantly different from baseline levels.
Group 2: Group 2 also significantly decreased intake of fats and oils at 6 weeks and 6 months. As in Group 1, there was no change in total milk and milk product consumption, but there was a significant increase in intake of skimmed milk at 6 weeks. In addition, consumption of meat and meat products was significantly lower at 6 weeks. This group significantly increased the per cent energy from fruits and fruit juices at all points post-intervention. There were no significant overall changes in the 'sugar, preserves and snacks' food group, but there were significant changes within this food group, in particular intake of crisps significantly decreased at 6 weeks.

A summary of the changes in nutrient and food intake between baseline, 6 weeks and 6 months for each group is presented in Table 5.

\section{Discussion}

The subjects in this study were volunteers from the Strathclyde Police Department. They were a group of educated, motivated subjects and therefore perhaps not 
Table 4 Changes in percentage energy derived from different food groups, showing the means and SD in parentheses

\begin{tabular}{|c|c|c|c|}
\hline & Baseline & 6 weeks & 6 months \\
\hline $\begin{array}{c}\text { Fats and oi } \\
\text { Group } 0 \\
\text { Group } 1 \\
\text { Group } 2\end{array}$ & $\begin{array}{l}5.7(3.15) \\
5.7(3.84) \\
5.8(2.41)\end{array}$ & $\begin{array}{l}5.8(2.91) \\
4.7(2.70) \\
3.8^{*}(2.94)\end{array}$ & $\begin{array}{l}5.5(2.83) \\
3.7^{\star}(3.20) \\
2.7 \dagger(1.97)\end{array}$ \\
\hline $\begin{array}{c}\text { Milk/milk pr } \\
\text { Group } 0 \\
\text { Group } 1 \\
\text { Group } 2\end{array}$ & $\begin{array}{r}9.0(5.84) \\
11.1(3.94) \\
8.7(4.81)\end{array}$ & $\begin{array}{l}8.6(3.84) \\
9.9(5.63) \\
9.5(5.32)\end{array}$ & $\begin{array}{r}8.8(5.33) \\
10.5(4.82) \\
9.1(5.27)\end{array}$ \\
\hline $\begin{array}{r}\text { Meat/meat } \\
\text { Group } 0 \\
\text { Group } 1 \\
\text { Group } 2\end{array}$ & $\begin{array}{l}14.9(7.45) \\
14.6(6.45) \\
16.7(6.82)\end{array}$ & $\begin{array}{l}14.2(6.52) \\
15.6(6.60) \\
14.8(6.81)\end{array}$ & $\begin{array}{l}16.8(7.50) \\
15.0(9.23) \\
16.8(8.93)\end{array}$ \\
\hline $\begin{array}{c}\text { Fish/fish pro } \\
\text { Group } 0 \\
\text { Group } 1 \\
\text { Group } 2\end{array}$ & $\begin{array}{l}2.7(2.79) \\
2.8(3.10) \\
3.0(2.81)\end{array}$ & $\begin{array}{l}3.1(3.43) \\
3.8(6.16) \\
4.0(3.64)\end{array}$ & $\begin{array}{l}2.6(3.67) \\
4.2(6.15) \\
2.6(3.63)\end{array}$ \\
\hline $\begin{array}{c}\text { Eggs/egg d } \\
\text { Group } 0 \\
\text { Group } 1 \\
\text { Group } 2\end{array}$ & $\begin{array}{l}2.0(2.22) \\
2.3(2.63) \\
3.2(2.96)\end{array}$ & $\begin{array}{l}2.1(2.37) \\
1.7(2.57) \\
2.3(3.07)\end{array}$ & $\begin{array}{l}1.6(3.29) \\
1.4(2.32) \\
3.2(4.61)\end{array}$ \\
\hline $\begin{array}{c}\text { Cereals/cer } \\
\text { Group } 0 \\
\text { Group } 1 \\
\text { Group } 2\end{array}$ & $\begin{array}{l}30.4(8.41) \\
28.8(6.87) \\
30.4(8.13)\end{array}$ & $\begin{array}{l}31.3(9.38) \\
33.1^{*}(8.22) \\
30.8(8.21)\end{array}$ & $\begin{array}{l}28.8(8.38) \\
33.1^{*}(10.31) \\
31.2(10.34)\end{array}$ \\
\hline $\begin{array}{c}\text { Fruit/fruit ju } \\
\text { Group } 0 \\
\text { Group } 1 \\
\text { Group } 2\end{array}$ & $\begin{array}{l}3.9(2.83) \\
4.8(4.32) \\
3.6(2.67)\end{array}$ & $\begin{array}{l}4.0(3.92) \\
4.4(3.12) \\
5.4^{*}(3.58)\end{array}$ & $\begin{array}{l}4.0(3.79) \\
4.9(3.83) \\
5.9^{*}(4.03)\end{array}$ \\
\hline $\begin{array}{c}\text { Vegetables } \\
\text { Group } 0 \\
\text { Group } 1 \\
\text { Group } 2\end{array}$ & $\begin{array}{l}12.7(5.19) \\
12.3(5.79) \\
10.8(4.76)\end{array}$ & $\begin{array}{l}10.4(5.17) \\
10.9(6.19) \\
10.5(4.89)\end{array}$ & $\begin{array}{r}12.7(7.14) \\
11.7(5.23) \\
9.8(4.23)\end{array}$ \\
\hline $\begin{array}{c}\text { Sugar/pres } \\
\text { Group } 0 \\
\text { Group } 1 \\
\text { Group } 2\end{array}$ & $\begin{array}{l}6.0(4.22) \\
7.2(4.47) \\
5.4(4.06)\end{array}$ & $\begin{array}{l}7.4(6.73) \\
4.3 \dagger(3.25) \\
5.5(4.11)\end{array}$ & $\begin{array}{l}5.6(4.73) \\
5.2(4.52) \\
5.8(4.66)\end{array}$ \\
\hline $\begin{array}{c}\text { Nuts and se } \\
\text { Group } 0 \\
\text { Group } 1 \\
\text { Group } 2\end{array}$ & $\begin{array}{l}3.0(2.04) \\
3.5(2.61) \\
2.9(2.17)\end{array}$ & $\begin{array}{l}3.1(2.57) \\
3.6(2.40) \\
3.1(2.78)\end{array}$ & $\begin{array}{l}3.0(2.88) \\
3.1(3.47) \\
3.6(3.37)\end{array}$ \\
\hline $\begin{array}{c}\text { Alcoholic be } \\
\text { Group } 0 \\
\text { Group } 1 \\
\text { Group } 2\end{array}$ & $\begin{array}{l}8.3(5.35) \\
5.8(7.05) \\
7.9(7.07)\end{array}$ & $\begin{array}{l}8.9(8.03) \\
7.5(10.06) \\
8.4(9.86)\end{array}$ & $\begin{array}{l}9.2(6.73) \\
6.7(7.52) \\
7.8(8.35)\end{array}$ \\
\hline $\begin{array}{c}\text { Beverages } \\
\text { Group } 0 \\
\text { Group } 1 \\
\text { Group } 2\end{array}$ & $\begin{array}{l}1.0(1.29) \\
0.8(0.98) \\
1.2(1.91)\end{array}$ & $\begin{array}{l}0.6(1.48) \\
0.5(0.97) \\
1.7(2.50)\end{array}$ & $\begin{array}{l}0.7(1.19) \\
0.4(0.88) \\
1.1(2.49)\end{array}$ \\
\hline
\end{tabular}

*Using a two-tailed $t$-test, values differ significantly from the baseline value in their group at a significance level of $P<0.05$.

†Using a two-tailed $t$-test, values differ significantly from the baseline value in their group at a significance level of $P<0.001$.

fully representative of the Scottish population as a whole. However, if nutrition education is not followed entirely by well-motivated individuals, we can assume that other groups in the clinical setting would respond less favourably.

Unfortunately we do not have information on those policemen who did not respond to the letter asking for volunteers, so we can not compare the characteristics of those taking part with those not taking part. The aim, however, was to test two types of dietary advice, which we achieved, using each subject as his own control, ensuring there were no fundamental differences between experimental groups at baseline.

These results suggest that subjects failed to sustain an 
Table 5 Changes in percentage energy from nutrients and pecentage energy from foods between baseline, 6 weeks and 6 months for Groups 0, 1 and 2

\begin{tabular}{lll}
\hline & \multicolumn{1}{c}{ Nutrient changes } & \multicolumn{1}{c}{ Food changes } \\
\hline Group 0 & No significant changes & No significant changes \\
Group 1 & Reduction in percentage energy from fats & Reduction in fats and oils \\
& Increase in percentage energy from carbohydrates & Decrease in full fat milk, increase in semiskimmed \\
& Increase in percentage energy from starch & milk \\
& Decrease in percentage energy from added sugar and & Decrease in crisps (6 weeks only) \\
& NME sugar (6 weeks only) & Increase in cereal products \\
& Increase in percentage energy from protein & Decrease in chocolate and biscuits (6 weeks only) \\
& Reduction in percentage energy from fat & Reduction in fats and oils and spreading fats \\
Increase in percentage energy from carbohydrates & Decrease in full fat milk, increase in fully skimmed \\
Increase in percentage energy from starch & milk \\
& Increase in percentage energy from total NME sugar & Decrease in crisps (6 weeks only) \\
& (6 weeks only) & Decrease in meat products (6 weeks only) \\
& Increase in percentage energy from protein & Small increases in squashes, cordials, sugars \\
& & syrups and preserves (NS)
\end{tabular}

initial simultaneous reduction in per cent energy from dietary fat and sugar when advised to do so. Groups 1 and 2, despite reducing their fat intake, had sugar intakes at 6 months post-intervention which were not significantly different.

Although the decrease in percentage of energy from sugar in Group 1 was not significant at 6 months, it still represents a reduction of $18 \%$ from baseline. It may be that a larger sample size may have increased the significance, assuming this trend remained uniform for the larger group. However, it is impossible to say whether this $18 \%$ reduction in sugar intake would be maintained long term, by a larger group, or whether sugar intakes would have gradually increased back to baseline levels over the following months.

The successful reduction in fat intakes in Group 2 when sugar intakes remained constant, could indicate a positive role for sugars in helping to maintain carbohydrate intakes. The group advised to reduce both fat and sugar (Group 1) did not increase absolute intakes of starch to counteract the energy deficit associated with the reduced absolute fat intakes. This resulted in a reduced reported total energy intake at 6 weeks and 6 months post-intervention. However this reported energy drop was not associated with a change in body weight or body fat percentage and could indicate underreporting. It appears therefore that for the 4-day record period there were individuals in this group who either decreased their energy intake or they were to some degree underreporting. We excluded individuals at baseline who reported intakes of less than $1.10 \times$ BMR. Since the nature of the study was to measure sugar and fat intakes, which often make up the foods prone to being underreported, such as savoury snacks and confectionery, we excluded these individuals assuming they would be unreliable reporters.

However, the effect of the specific dietary advice to Group 1 may have contributed to these low recordings of energy intake. Group 1 were advised to reduce intakes of both sugary and fatty foods and it may be that these foods were subsequently underreported, even in this group of initially valid reporters. Alternatively, it may be difficult to find foods low in fat and sugar and it could be that for the 4-day recording period the subjects in Group 1 just ate less, avoiding these foods to adhere to the dietary advice, but consumed them at other times. The group advised to reduce fat only (Group 2) maintained energy intakes at 6 months by a non-significant increase in absolute intakes of starch and total sugars. Intakes of NME sugars remained constant throughout the intervention.

When examining differences between groups at baseline, there was a significant difference between the per cent energy from fat between Group 0 and Group 2, with Group 2 being significantly higher. Since subjects were randomly assigned to one of the three groups, this difference is probably spurious as there were no other significant differences between groups at baseline, including absolute fat intakes.

It appears that both Groups 1 and 2 achieved a reduction in percentage energy from fat by making relatively small adjustments to their habitual diet, e.g. changing from whole milk to semi- or skimmed milk, reducing intakes of spreading fats, animal fats and oils and meat products. This concurs with Black et al. ${ }^{7}$ who noted that those achieving the recommended level for dietary fat chose skimmed milk, low fat meats with all visible fats trimmed, rarely ate meat products and ate less spreading fats. They concluded that the cumulative effect of small changes were sufficient to achieve a fat intake similar to the recommended level, and advice to individuals should be to help them modify their diet without changing the essential character of their diet if the changes are to be maintained long term.

Other differences included Group 2 significantly increasing fruit consumption at 6 weeks and 6 
months whereas Group 1 showed no increase in fruit consumption at 6 weeks or 6 months despite being advised to replace high sugar snacks with fruit. High intakes of fruit may be characteristic of individuals achieving a low fat $\operatorname{diet}^{22}$. Group 1 were advised to reduce intakes of confectionery and sweet biscuits, which they achieved at 6 weeks but by 6 months they had increased intakes back to baseline levels. This is reflected in the percentage energy from NME sugars reverting back to baseline levels after an initial reduction. In Group 2, which received advice only on fat with ad lib sugars, there were no changes in intakes of confectionery and sweet biscuits.

\section{Conclusions}

This study of middle-aged men aimed to look at the impact of advice given to free-living subjects over a period of 6 months. The advice was successful in encouraging a sustained reduction in percentage energy from fat and could provide a model for further studies and clinical approaches. The results suggest that subjects are more able to comply long term when a single message to reduce dietary fat is given. Multiple messages to reduce both percentage energy from fat and sugar resulted in a significant reduction in percentage energy from fat and sugar in the short term only, with the effect of the advice for sugar diminishing between 6 weeks and 6 months.

In conclusion, well-motivated male subjects were not able to sustain two population-based dietary goals set by the Scottish Office, namely to reduce energy from both fat and sugar. However, a single dietary message to reduce fat alone was successfully achieved long term after only one session of dietary advice.

\section{Acknowledgements}

The authors would like to thank the Sugar Bureau for their sponsorship of this work.

\section{References}

1 NACNE. A Discussion Paper on the on the Proposals for Nutritional Guidelines for Health Education in Britain. London: Health Education Council, 1993.

2 Department of Health. Dietary Reference Values for Food, Energy and Nutrients for the United Kingdom. Report of the Panel on Dietary Reference Values of the Committee on Medical Aspects of Food Policy (COMA). London: HMSO, 1991.

3 Department of Health. Eat Well! An Action Plan from the Nutrition Task Force to Achieve the Health of the Nation Targets on Diet and Nutrition. London: Department of Health, 1994.

4 Scottish Office Home and Health Department. Scottish Health: a Challenge to Us All. Report of the Working Party to the Chief Medical Officer for Scotland. Edinburgh: Scottish Office Home and Health Department, 1993.
5 Cade J, Booth S. What can people eat to meet dietary goals and how much does it cost? J. Hum. Nutr. Diet 1990; 3: 199207.

6 Bradley A, Theobald A. The effects of dietary modification as defined by NACNE on eating habits of 28 people. J. Hum. Nutr. Diet 1988; 1: 105-14.

7 Black AE, Ravenscroft C, Sims AJ. The NACNE report: are the dietary goals realistic? Comparisons with the dietary patterns of dietitians. Hum. Nutr. Appl. Nutr. 1984; 39A: 165-79.

8 Cole-Hamilton I, Gunner K, Leverkus C, Starr J. A study among dietitians and adult members of their households and the practicalities and implications of following proposed dietary guidelines for the UK. Hum. Nutr. Appl. Nutr. 1986; 40A: 365-89.

9 Gibney MJ, Maloney M, Shelly E. The Kilkenny Health Project: patterns of food intake in individuals consuming low-, moderate-, or high-fat diets. Proc. Nutr. Soc. 1997; 46: 14A.

10 McColl KA. The sugar-fat seesaw. Nutr. Bull. 1988; 13: 114-19.

11 Nelson M. Nutritional goals from COMA and NACNE: How can they be achieved? Hum. Nutr. Appl. Nutr. 1985; 39A 456-64.

12 Naismith DJ, Rhodes C. Adjustment in energy intake following the covert removal of sugar from the diet. $J$. Hum. Nutr. Diet 1995; 8: 167-75.

13 Lavin JH, French SJ, Read NW. The effect of sucrose- and aspartame-sweetened drinks on energy intake, hunger and food choice in female, moderately restrained eaters. Int. J. Obes. 1997; 21: 37-42.

14 Durnin JVGA, Womersley J. Body fat assessed from total body density and its estimation from skinfold thickness: measurements on 481 men and women aged from 16-72 years. Br. J. Nutr. 1974; 32: 77-97.

15 Ministry of Agriculture, Fisheries and Food. Food Portion Sizes, 2nd edn. London: HMSO, 1994.

16 Paul AA, Southgate DAT. McCance and Widdowson's The Composition of Foods, 4th edn. London: HMSO, 1978.

17 Holland B, Welsh AA, Unwin ID et al. McCance and Widdowson's The Composition of Foods, 5th edn. London: Royal Society of Chemistry/Ministry of Agriculture, Fisheries and Food, 1991.

18 Bolton-Smith C, Woodward M. Intrinsic, non-milk extrinsic and milk sugar consumption by Scottish adults. J. Hum. Nutr. Diet 1995; 8: 35-49.

19 Buss DH, Lewis J, Smithers G. Non-milk extrinsic sugars. $J$. Hum. Nutr. Diet 1994; 7: 87 .

20 Goldberg GR, Black AE, Jebb SA et al. Critical evaluation of energy intake data using fundamental principles of energy physiology: derivation of cut-off limits to identify underreporting. Eur. J. Clin. Nutr. 1991; 45: 569-81.

21 Schofield WN, Schofield C, James WPT. Basal metabolic rate - review and prediction, together with an annotated bibliography of source material. Hum. Nutr. Clin. Nutr. 1985; 39 (Suppl.): 1-96.

22 Flynn MAT, Sugrue DD, Gibney MJ. Woman's dietary fat and sugar intakes: implications for food based guidelines. Eur.J. Clin. Nutr. 1996; 50: 713-19.

\section{Appendix 1: Booklet given to Group 1 summarizing advice to reduce intake of both dietary fats and sugar}

\section{Eating for a bealthy beart}

Eating a healthy diet can help prevent many diseases, including heart disease which is one of the greatest causes of death in Scotland. The most important change we can make to our diet to make it healthier is to decrease the total amount of fat we eat. One benefit of a low fat diet is that it can help prevent the build up of cholesterol on the walls of the blood vessels that supply blood to the heart. If this was 
allowed to continue it could result in what is commonly known as a heart attack.

However not only can a diet low in fat help prevent this, but it may reverse any damage already done - so it is never too late to start eating healthily! Eating healthily doesn't mean just cutting out the fatty foods. Instead we should substitute these foods by eating a varied diet packed with fresh fruit and vegetables, lean meat, chicken and fish, pasta and rice, and much more, as you will read in the following pages!

\section{Fats in our diet}

Where are the fats in our food? Some of the fats in our food is 'visible' like the fat on meat and the butter or spread we put on our bread. Visible fat is easy to spot and cut out. Other fat is called 'invisible' because it is difficult to see, and often we are not aware of it, for example the fat incorporated into certain 'fatty' cakes and biscuits, and in foods which are fried, crumbed or battered. It is also present in dairy foods like cream and cheeses as well as meat and meat products.

Which foods contain most fats? Foods rich in fats are most animal products, including fatty cuts of beef, lamb, pork, other meat products such as sausages, meat pies, burgers, dairy products such as cream, full fat milk, cheese and butter, and certain cakes and pastries.

\section{Ten simple changes to reduce fats}

$\mathbf{1}$ Grill instead of fry.

2 Change from full fat milk to semiskimmed which has half the fat, or to skimmed milk which contains virtually no fat.

3 Choose medium or low fat cheese, such as edam, cottage cheese or reduced fat cheese in cheese dishes.

4 Choose poultry, fish or lean red meat in place of fattier meat or meat products, like hamburgers or pork pies.

5 Always cut any visible fat off meat before cooking and look for low fat options at the butchers or supermarkets.

6 Most of the fat in chicken and other poultry is just under the skin. Take the skin off and the fat will come with it.

7 When cooking mince and other meat dishes, pour off any extra fat before thickening

8 When making meat dishes, buy a little less of the leanest meat rather than a larger quantity of the fattier meat and bulk up with extra vegetables and pulses such as peas, lentils and beans.

9 Use low fat natural yoghurt and fromage frais instead of cream in soups, casseroles and on desserts.

10 Avoid chips and roast potatoes, instead try boiled or jacket potatoes.

\begin{tabular}{|c|c|}
\hline $\begin{array}{l}\text { Alternative food choices } \\
\text { Choose these: }\end{array}$ & $\begin{array}{l}\text { eplace fatty foods } \\
\text { Instead of these: }\end{array}$ \\
\hline $\begin{array}{l}\text { Cottage cheese, edam, } \\
\text { reduced fat cheese }\end{array}$ & $\begin{array}{l}\text { Cheddar cheese, stilton, full } \\
\text { fat cheese }\end{array}$ \\
\hline $\begin{array}{l}\text { Skimmed or semiskimmed } \\
\text { milk }\end{array}$ & Whole milk \\
\hline $\begin{array}{l}\text { Low fat yoghurt or fromage } \\
\text { frais }\end{array}$ & Cream \\
\hline Lean meat, poultry, fish & $\begin{array}{l}\text { Fatty meat, meat products } \\
\text { (pies, sausages, pâté, } \\
\text { burgers) }\end{array}$ \\
\hline
\end{tabular}

Grilled, poached, steamed or boiled foods

Reduced fat mayonnaise and salad dressings

Reduced fat spreads

Boiled and baked potatoes, oven chips

Porridge and other breakfast cereals

\section{Sugars in out diet}

From the analysis of your normal diet, it may be beneficial for you to reduce the amount of sugar you eat. Sugar has been linked to poor dental health. Although sugar tastes good it does not contain any nutrients apart from calories, and frequent consumption of sugary foods and drinks has been linked to poor dental health.

\section{Seven simple changes to reduce sugar}

1 Try to drink your tea and coffee without sugar. You might find it easier to cut down gradually, or use artificial sweeteners.

2 Use unsweetened fruit juice or low calorie soft drinks rather than ordinary soft drinks which have a lot of sugar.

3 Choose fresh fruit or canned fruit in natural fruit juice rather than syrup as an optional dessert.

4 Avoid sweets, chocolates and biscuits, cakes and puddings and desserts, or choose desserts which state they are reduced in sugar or contain artificial sweeteners.

5 Use less sugar in cooking.

6 Avoid sweetened breakfast cereals, instead choose Weetabix, Cornflakes, Special K, Bran Flakes, unsweetened muesli, etc. (see list).

7 When buying packaged foods make sure sugar is not one of the ingredients at the top of the list, since the ingredients are listed in order of quantity.

\section{‘Green light' low fat foods!}

Starchy foods: Bread (with a reduced fat spread used sparingly); pasta (with a tomato-based sauce rather than a creamy sauce); rice (boiled not fried); potatoes (boiled or baked, not roasted or fried, oven chips only).

Vegetables: All green vegetables, such as cabbage, broccoli, Brussels sprouts; all pulses, such as peas, beans and lentils; all root vegetables, such as carrots and turnips; all salad vegetables, such as lettuce, peppers, tomatoes and cucumbers.

Fruit: All fresh fruit; tinned fruit in its own natural unsweetened juice; fruit juice, unsweetened only.

Meats, poultry and fish: Lean cuts of red meat, with all visible fat removed; chicken (without skin); fish (not fried).

Eggs: Boiled, scrambled or poached.

Cereals: Only unsweetened breakfast cereals, without sugar added (such as Weetabix, porridge, Allbran, Sultana Bran, Bran Flakes, unsweetened muesli, Common Sense Oat Bran, 
Fruit and Fibre, Raison Splitz, Shredded Wheat, Shreddies, Special K, Rice Krispies).

Dairy products: Skimmed or semiskimmed milk; low fat yoghurt; very low fat fromage frais; cottage cheese; edam cheese; reduced fat cheeses.

Puddings and desserts: Low fat puddings and desserts, sweetened with artificial sweeteners only.

\section{Appendix 2: Booklet given to Group 2 summarizing advice to reduce intake of dietary fat only}

\section{Eating for a bealtby beart}

Eating a healthy diet can help prevent many diseases, including heart disease which is one of the greatest causes of death in Scotland. The most important change we can make to our diet to make it healthier is to decrease the total amount of fat we eat. One benefit of a low fat diet is that it can help prevent the build up of cholesterol on the walls of the blood vessels that supply blood to the heart. If this was allowed to continue it could result in what is commonly known as a heart attack.

However not only can a diet low in fat help prevent this, but it may reverse any damage already done - so it is never too late to start eating healthily! Eating healthily doesn't mean just cutting out the fatty foods. Instead we should substitute these foods by eating a varied diet packed with fresh fruit and vegetables, lean meat, chicken and fish, pasta and rice, and much more, as you will read in the following pages!

\section{Fats in our diet}

Where are the fats in our food? Some of the fats in our food is 'visible' like the fat on meat and the butter or spread we put on our bread. Visible fat is easy to spot and cut out. Other fat is called 'invisible' because it is difficult to see, and often we are not aware of it, for example the fat incorporated into certain 'fatty' cakes and biscuits, and in foods which are fried, crumbed or battered. It is also present in dairy foods like cream and cheeses as well as meat and meat products.

Which foods contain most fats? Foods rich in fats are most animal products, including fatty cuts of beef, lamb, pork, other meat products such as sausages, meat pies, burgers, dairy products such as cream, full fat milk, cheese and butter, and certain cakes and pastries.

\section{Ten simple changes to reduce fats}

1 Grill instead of fry.

2 Change from full fat milk to semiskimmed which has half the fat, or to skimmed milk which has virtually no fat at all.

3 Choose medium or low fat cheese, such as edam, cottage cheese or reduced fat cheese.

4 Choose poultry, fish or lean red meat in place of fattier meat or meat products, like hamburgers or pork pies.

5 Always cut any visible fat off meat before cooking and look for the low fat options at the butchers or supermarkets.

6 Most of the fat in chicken and other poultry is just under the skin. Take the skin off and the fat will come away with it.
7 When cooking mince and other meat dishes, pour off any extra fat before thickening.

8 When making meat dishes, buy a little less of the leanest meat rather than a larger quantity of the fattier meat and bulk up with extra vegetables and pulses such as peas, lentils and beans.

9 Use low fat natural yoghurt and fromage frais instead of cream in soups, casseroles and on desserts.

10 Avoid chips and roast potatoes, instead try boiled or jacket potatoes.

$\begin{aligned} & \text { Alternative food choices to replace fatty foods } \\ & \text { Choose these: }\end{aligned}$
$\begin{aligned} & \text { Cottage cheese, edam, } \\ & \text { reduced fat cheese }\end{aligned}$
$\begin{array}{ll}\text { Skimmed or semiskimmed } \\ \text { milk }\end{array}$

Low fat yoghurt or fromage Cream frais

Lean meat, poultry, fish

Grilled, poached, steamed or boiled foods

Reduced fat mayonnaise and salad dressings

Reduced fat spreads

Boiled and baked potatoes

Jams and marmalade

Cakes and biscuits

(only those listed)

Sorbets and non-dairy ice-cream

Breakfast cereals (sweetened or not)

Cordials, squashes and fizzy drinks

Pickles, chutneys, relishes and table sauces

Fatty meat, meat products (pies, sausages, pâté, burgers)

Shallow or deep fried foods

Traditional mayonnaise, oily salad dressings

Butter and full fat margarines

Chips and roast potatoes

Butter, margarine

Crisps, nuts and other savoury snacks

Traditional full fat ice-cream

Fried breakfast

Milk shakes and other milky drinks

Mayonnaise and oily dressings

\section{'Green light' low fat foods!}

Starchy foods: Bread (with a reduced fat spread used sparingly); pasta (with a tomato-based sauce rather than a creamy sauce); rice (boiled not fried); potatoes (boiled or baked, not roasted or fried, oven chips only).

Vegetables: All green vegetables, such as cabbage, broccoli, Brussels sprouts; all pulses, such as peas, beans and lentils; all root vegetables, such as carrots and turnips; all salad vegetables, such as lettuce, peppers, tomatoes and cucumbers.

Fruit: All fresh fruit; tinned fruit in its own natural juice or syrup; fruit juice, sweetened or unsweetened.

Meats, poultry and fish: Lean cuts of red meat, with all visible fat removed; chicken (without skin); fish (not fried). 
Eggs: Boiled, scrambled or poached.

Cereals: All breakfast cereals, sweetened or unsweetened, with or without sugar added.

Dairy products: Skimmed or semiskimmed milk; low fat yoghurt; very low fat fromage frais; cottage cheese; edam cheese; reduced fat cheeses.

Puddings and desserts: Low fat puddings and desserts only (see list).

Cakes and biscuits: Low fat or reduced fat cakes and biscuits only (see list).

\section{Itemized low fat foods}

- All breakfast cereals: Alpen, all muesli, Crunchy Nut Cornflakes, Coco Pops, Original Crunchy, Honey Nut Loops, Ricicles, Harvest Crunch, Sugar Puffs, Pop Tarts, sugar frosted flakes.

- Sweet biscuits: digestive (light), Ginger Nut, Jaffa Cake, Rich Tea, Abbey Crunch, Fig Roll, Garibaldi, chocolate teacake, Morning Coffee, Nice.

- Savoury biscuits: cracked wheat thin, cream cracker, Krisp Wheat.
- Cakes: Battenburg, rich fruit cake, iced fruit or iced jam ring, meringue (without cream), sponge finger, almond slice, fruit pies, French fancy, jam Swiss roll, lemon meringue, ginger cake, chocolate roll with jam filling, jam tart, raison and walnut malt loaf.

- Desserts: Ambrosia low fat custard or low fat rice, crème caramel, Strawberry Supreme, summer pudding, jellies, instant whip, strawberry sponge pudding, rhum baba, fruit puddings, syrup sponge pudding, Mullerice (strawberry or apple), sorbets, fruit ice lollies, Strawberry Split, non-dairy ice-creams, frozen yoghurt, raspberry ripple ice-cream.

- Soft drinks: all fizzy drinks, fruit juice and cordials.

- Hot drinks: low fat hot chocolate and malted drinks.

- Fruit: all fresh and tinned fruit in syrup.

- Sauces: brown sauce, tomato sauce, pickles, relishes, chutney.

- Spreads: jams, jellies, marmalade, honey, lemon curd, mince meat.

- Sweets and chocolates: fruit gums, Dolly Mixtures, Jelly Beans, Liquorice Allsorts, Fruit Pastilles, butterscotch, mint humbugs, sherbet fruits, traditional fudge, Five Centres, orange cream, Turkish Delight, Milky Way, Opal Fruits, Skittles, Tunes, After Eight's, Polos, Smarties, all boiled sweets, table sugar.

- Yoghurts and fromage frais: low fat and very low fat yoghurts, very low fat fromage frais. 